\title{
The Effect of Perceived Lender Characteristics and Market Conditions on Strategic Mortgage Defaults
}

\author{
Michael J. Seiler
}

(C) Springer Science+Business Media, LLC 2012

\begin{abstract}
Inequity Aversion has long been applied in a game theoretic setting to explain that individuals are willing to sacrifice personal wealth in order to financially penalize players they perceive to be acting selfishly or unfairly. I apply inequity aversion to strategic mortgage default decisions and find that individual homeowners (as well as a second sample of professional mortgage lenders) have a differential stated willingness to walk away from their mortgage based on the perceived characteristics of their lender. Importantly, these significant differences can be removed even with extremely modest loan modifications. Finally, I document that regular homeowners and even professional lenders do a poor job differentiating between the owner of their loan and the servicer of their loan. This is particularly troubling given the extreme misconception of their bank's true character. As a result, much of their willingness to penalize is misplaced resulting in an unnecessary number of strategic mortgage defaults.
\end{abstract}

Keywords Strategic mortgage default · Loan modifications · Inequity aversion · Lender characteristics

\section{Introduction}

An economic default on one's mortgage is said to occur when the homeowner can no longer afford to make his monthly payments and has no choice but to stop paying. Alternatively, a strategic mortgage default is when the homeowner can continue making his payments, but elects not to. While the appropriate metric for how to differentiate between an economic versus strategic default is heavily debated, Wyman

I would like to thank the Mortgage Bankers Association for providing proprietary data for this study. Any errors and omissions remain my own.

M. J. Seiler $(\bowtie)$

Real Estate and Economic Development, Old Dominion University, 2154 Constant Hall, Norfolk, VA 23529-0223, USA

e-mail: mseiler@odu.edu 
(2010) estimates that $17 \%$ of all defaults are strategic, while Guiso et al. (2012) claim the number is closer to $26 \%$. Moreover, understanding the nature and causes of strategic default is critical as Wyman (2010), White (2010), FICO (2011), and Guiso et al. (2012) convincingly demonstrate that the increasing occurrence of strategic default is a key factor in preventing an economic recovery. ${ }^{1}$

White (2010), Guiso et al. (2012), and Seiler et al. (2012a) all find that in addition to economic factors, emotional considerations also play an important role in the strategic default decision-making process. While these studies have examined a multitude of the emotional considerations that underlie homeowner actions, no study has examined the role that perceptions of bank characteristics have on the decision to strategically default. Borrowing from the ultimatum game literature, ${ }^{2}$ where economic decision-makers regularly and voluntarily leave money on the table in order to penalize players who make selfishly low offers, ${ }^{3}$ I hypothesize that when a homeowner is deciding whether or not to strategically default on his mortgage, he considers the character of his bank. For example, if a homeowner is teetering on the brink of default and perceives his bank to be a predatory lender that engages in deceptive lending practices and has received government bailout funds, he will find it a little easier to stop making payments. Alternatively, if the homeowner originated the loan through a local bank (who still owns the loan today) where his loan officer is a friend, he will be less likely to walk away from his mortgage obligations. Consistent with the Fehr and Schmidt (1999) theory of inequity aversion, I interpret this behavior as being reflective of the borrower's utility function including more than just maximizing personal wealth.

I further demonstrate that when even a modest modification is granted, the bank sends a strong cooperation signal to the borrower which completely changes that borrower's perceived image of the lender. Whereas rejecting a loan modification request signals a lack of cooperation, and therefore an increase in the borrower's desire to penalize the bank, granting a loan modification (even an extremely modest one that has little direct economic impact on the performance of the loan) signals that the lender is not playing against, but rather with the borrower in the ultimatum game (Rabin 1993). This willingness to work with a borrower makes the lender seem more reasonable and deserving of trust and reciprocity resulting in a significantly reduced incidence of strategic mortgage default.

Given the well-documented egregious behavior of many lenders across the country throughout the mortgage crisis, and knowing that homeowners include emotional as well as economic factors when considering strategic default, I examine the role that borrower perceptions of his lender have on his stated willingness to strategically default. I find that homeowners' willingness to

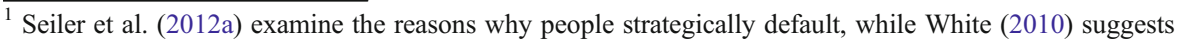
possible solutions to the problem.

${ }^{2}$ The ultimatum game involves a single decision game where two players split a sum of money. The first player decides how much of the money to offer to the second. The second player simply accepts or rejects the offer. If Player 2 accepts, both parties keep the money. If he rejects, neither party keeps anything. Using a strict "homo economicus" definition of utility-maximizing, it is rational for the second player to accept any non-zero offer. Yet, study after study reveals that individuals will voluntarily reject positive monetary offers to penalize selfish, or unfair, players. The conclusion is that people's utility functions incorporate more than just wealth maximization. People also care about being treated with respect and fairness.

${ }^{3}$ See Kahneman et al. (1986).
} 
default is significantly greater when working with (nameless/faceless) on-line banks than when working with local banks with whom they have an ongoing relationship. Similarly, I also find that borrowers are significantly more willing to strategically default when dealing with egregious banks as opposed to financially conservative ones who did not engage in excessive risk-taking and deceptive lending practices. These findings remain robust when collecting a second sample of homeowners who are also professional mortgage lenders.

Interestingly, both samples are found to have extreme misconceptions that directly relate to the perception of their bank's character. Specifically, both groups erroneously believe the servicer of their loan is also the entity who owns the loan $(77.4 \%$ and $89.2 \%$ of the time). Moreover, homeowners in my sample believe the number of bailed out banks to be two to three times greater than it really is. Worse yet, when asked which banks received bailout funds, homeowners in my first sample were only correct $55.04 \%$ of the time, not significantly different from a coin flip. More surprisingly, mortgage lenders who work in the business correctly classified bailed out banks only $52.27 \%$ of the time. This misinformation represents a great potential for misplaced anger/frustration by disheartened borrowers potentially leading to illconceived reasons to strategically default.

Predictors of increased willingness to strategically default include being turned down for a modification, having previously defaulted, having a higher positive net worth, being less than 45 years old, and being a male. Finally, both groups of homeowners in my sample agree that if a modification were to be performed, a principal reduction, resulting in the exact same monthly payment change as a corresponding interest rate reduction, would result in a lower incidence of strategic default. This stated opinion is statistically confirmed by revealed preference measures which constitute the major contribution of this study.

This study proceeds as follows: In "Literature Review", I discuss the extant literature relating to the burgeoning concept of strategic mortgage default as well as the application of ultimatum games whose concepts apply to my central hypotheses. "Methodology" describes the methodology used to measure the perceptions of borrowers as it relates to their bank's behavior, while "Data" reports my data collection effort. I demonstrate that homeowner perceptions do not match reality in "Results". Finally, I conclude with what this perceptions mismatch means to the lending industry and how the industry might incorporate this knowledge into policies moving forward.

\section{Literature Review}

\section{Strategic Mortgage Default}

Lacour-Little (2008) provides a thorough review of the literature surrounding (economic) mortgage defaults which is rich with theory and evidence identifying the mechanisms that lead to this major economic event. But, it wasn't until very recently that studies attempted to differentiate between an economic default (where the borrower simply cannot afford to pay his mortgage) and a strategic default (where the borrower can afford to pay his mortgage, but decides not to). Wyman (2010), 
FICO (2011), and Guiso et al. (2012) provide a simple explanation as to why strategic mortgage defaults are on the rise. These authors conclude that a necessary condition is that the borrower is underwater on his mortgage. The borrower can afford to continue paying his mortgage, but is no longer interested in making (often negative net cash flow) payments on an asset that has increasingly negative equity with poor prospects of turning around in the foreseeable future.

Notwithstanding the harsh ramifications associated with the decision to strategically default as summarized in such recent studies as Seiler et al. (2012a) and FICO (2011), individuals continue to be willing to make the leap of faith that they will be better off walking away from their mortgage than continuing to pay it. Disadvantages to walking away include a substantially reduced FICO score, a greater expense and difficulty obtaining future credit, moving expenses, potential social backlash from family and friends, possible tax implications, and the chance of the lender pursing a deficiency judgment. The main perceived advantage, of course, is that the lender may decide not decide to come after the borrower for the deficiency amount.

Even though $25 \%$ of all borrowers across the country have a loan-to-value (LTV) ratio above $100 \%$ (i.e., they are underwater), ruthless default remains uncommon. Of the mortgages that are in default, only $17 \% \sim 26 \%$ are deemed to be strategic in nature. Clearly, there are known and substantial risks associated with the decision to strategically default making negative equity a necessary, but certainly not sufficient condition to walk away. In the current investigation, I fill a major gap in the literature by examining the role that the perceived character of the lender plays in the decision to strategically default on one's mortgage.

\section{Defining Strategic Default}

Strategic Defaulters are a top concern for the lending industry, yet traditional credit risk metrics are not sufficient to identify them (FICO 2011). The difficulty lies in what it means to be able to afford continued mortgage payments. Consider a borrower who claims he cannot afford to make his payments (an economic default). Might he be able to make his payment if he put in more hours at work, took on a second job, cut back on his spending, accessed unused credit lines, maximized credit card debt, sold off some of his assets, tapped his savings, retirement account or child's education fund? Seiler et al. (2012a) identified strategic defaulters by allowing them to self-select into one of three distinct survey pools of participants, and then examined the extent to which strategic defaulters did many of the above listed activities before defaulting on their loan.

Guiso et al. (2012) also used a survey approach, but instead of having actual borrowers self-select, the authors asked two questions to all survey participants (many of which are presumably not even homeowners): "How many people do you know who have defaulted on their house mortgage?" and "Of the people you know who have defaulted on their mortgage, how many do you think walked away even if they could afford to pay the monthly mortgage?". The authors then divided the two numbers to arrive at the percentage of all borrowers who strategically defaulted. This approach was heavily scrutinized in Seiler et al. (2012a) on a number of fronts. For example, most defaulting borrowers do not tell others they defaulted, much less that they strategically defaulted. Moreover, Seiler et al. (2012a) finds that if strategically defaulting borrowers do share the information with others, they will not be 
consistently truthful when telling family members versus friends versus acquaintances. Hence, deriving a measure based on hearsay from a typically non-forthcoming source seems unreliable and inconsistent, at best.

A more quantitative, but indirect, method to identify strategic defaulters is employed by Wyman (2010) and Fico (2011). While neither will disclose their exact formulas for proprietary reasons, both organizations consider mortgages that are either 60 or $90 \mathrm{dpd}$ (days past due). They then consider if the borrower has other trade lines (credit cards, auto loans, and other personal loans) that are current. If the borrower can "afford" to make all other payments on time, but is only behind on his mortgage, these organizations deem the borrower to be defaulting by choice. While quantification has a way of comforting those in need of identifying such fuzzy concepts, strategic mortgage default remains an elusive act to classify.

\section{Ultimatum Games}

The first ultimatum game was developed by Güth et al. (1982) and is played as follows: A moderator explains that a sum of money is to be given to both players. Player 1 determines the exact split of the money. Player 2 then decides if he will accept or reject the offer. If Player 2 accepts the offer, both players keep the money based on how Player 1 proposed it to be divided. If Player 2 rejects the offer, neither player gets anything. If Player 2 has a utility function based strictly on maximizing wealth, the Nash equilibrium is that he will always accept any non-zero offer as doing so will add to his wealth level. ${ }^{4}$

The ultimatum game has been repeated over and over again across a wide range of settings, and while the environment has changed, the one thing that has remained constant is that if Player 2 receives too low an offer (still greater than $\$ 0$ ), he will reject the offer, sacrificing personal wealth in order to penalize Player 1 for his perceived selfishness. The conclusion to be drawn is that as explained by inequity aversion in Fehr and Schmidt (1999), individuals care about more than money; they care about fairness and being treated with respect. And when they perceive a person as not being equitable, they derive more utility from seeing them get penalized than they do from receiving extra money.

Neurological experiments by Sanfey et al. (2003) have documented that when Player 2 receives too low an offer, an area of the brain known as the insular cortex (which is associated with feelings of disgust) becomes very active. I argue that the underlying concept of inequity aversion found within such game theory applications as the ultimatum, altruism, trust, and dictator games can be applied to loan modifications as well. When a borrower requests a loan modification, the lender decides if that offer will be accepted or not. If the lender rejects the modification offer, the borrower can feel high levels of disgust, frustration, and/or inequity. The borrower's only method to punish the bank is to default on his mortgage. Clearly, a borrower will not take such an extreme measure in all circumstances. But, if the borrower is already considering strategic mortgage default, being rejected for a loan modification by a

\footnotetext{
${ }^{4}$ Both players know the game is played with only a single round, and that there will be no chance to ever play again. Thus, considerations of reciprocation and subsequent cooperation are removed.
} 
bank he perceives to be selfish or egregious might be reason enough to allow him the justification to stop paying his mortgage.

\section{Methodology}

This study examines the effect of perceived bank characteristics on the stated willingness of borrowers to strategically default on their mortgage. The reason I examine a borrower's perception of their lender is that it is perceptions of the lender's character, not the lender's actual character, which enters into the individual's strategic default decision-making process. Alternatively stated, I hypothesize that if a borrower believes his bank has engaged in predatory lending practices, excessive risk-taking, and received government bailout funds, he will be much more willing to strategically default at the margin. The fact that the homeowner may be misinformed about his bank's behavior does not change his actions. As such, I do not approach this study by examining the actual behavior of banks and attempt to link their actions to loan performance. Doing so would mistakenly assume that homeowners correctly assess and accurately perceive the actions/ behavior of their lenders. To confirm the appropriateness of my approach, I demonstrate later in the paper that homeowners (even homeowner professionals within the lending industry) have a surprisingly poor understanding of the loan servicer-owner relationship, how many banks received bailout funds, and even if their bank received bailout funds.

Since I am focused in this study on perceptions and because perceptions are not directly observable using existing datasets, I begin by employing a "between subjects" experimental design. That is, I create an environment where only one variable at a time changes from one homeowner sub-sample to the next. Since only one variable changes between groups, I attribute the change in stated willingness to strategically default to the change made in the experimental design. In the current investigation, I focus on four key bank attributes (local versus on-line banks; financially conservative versus banks with egregious behavior), two economic environments (an environment where mortgage defaults are rare versus one where defaults are common), and three potential modification outcomes (no modification; an interest rate reduction resulting in a reduced monthly payment by $\$ 100$; and a principal reduction resulting in a monthly payment reduction of $\$ 100)$. This results in 21 (6 environments $\times 3$ modification outcomes +3 control groups) total variants of my experiment. ${ }^{5}$ Again, only one variant is inserted into the experimental design at a time. Hence, I follow a standard "between subjects" design.

\section{Data}

While most studies employing an experimental design collect data in a face-toface setting using a convenience sample of college students, I do not feel this approach is appropriate given that homeownership is not typically achieved by

\footnotetext{
${ }^{5}$ A complete description of the study's experimental design is available from the author upon request.
} 
college students. Moreover, I want to broaden my sample to the entire United States to remove concerns over the ability to generalize my results. For these reasons, I collect my core sample using an anonymous, web-based instrument accessing homeowners from across the entire United States. The current study uses the same approved network of homeowners and methods of data collection as Seiler et al. (2012a)) and b. ${ }^{6}$ The result is a sample of 880 homeowner participants. ${ }^{7}$

In comparing the demographics of my collected sample to that of the national database of homeowners, I find that my sample is somewhat younger. Otherwise, the demographic profiles between the two groups are quite comparable in terms of ethnic make-up, income, marital status, and gender. Specifically, my sample relative to national homeowners found in the American Housing Survey and American Community Survey consists of White $(87.3 \%$; $81.0 \%$ ), Black (4.7\%; $8.0 \%)$, and Hispanic (2.2\%; $3.1 \%)$, respectively. The average income in the sample is $\$ 69,000$, whereas the national average homeowner income is $\$ 60,000$. Finally, $66.1 \%$ of my respondents are married compared to $52.3 \%$ of the national homeowners who are married. Where the samples differ are in terms of age (37.2 versus 52), respectively.

As a robustness check, and to be consistent with Seiler et al. (2012b), I also collected a second sample. Instead of just focusing on regular homeowners, I collected data from the local chapter of the Mortgage Bankers Association (MBA) at a regularly scheduled meeting. ${ }^{8}$ Since the issues addressed in this study directly relate to their core line of business, I felt this was an opportunity to test my research questions under a greater level of scrutiny. This second sample consists of a live audience made up of 36 MBA members where data was collected in real time via an Instant Response Device (IRD). ${ }^{9}$ Since it is not possible or practical to divide the MBA audience into multiple sub-samples (as I effectively did for sample 1), I employ a "within subjects" design and test only four of the 21 variants. The variants considered include the four key bank attributes (local versus on-line banks; financially conservative versus banks with egregious behavior) where no modification was granted by the lender.

\footnotetext{
${ }^{6}$ Please see these two studies for a thorough explanation of the process of ensuring the collection of high quality data. To be clear, while the general national pool of homeowners is accessed, the current investigation in no way shares the same dataset as these other studies. I simply access the same network of homeowners, but with a completely different purpose and data collection instrument.

${ }^{7}$ Experimentally collected data should not be viewed as mere survey data. However, the two are unfortunately often confused. Still, survey-based datasets such as the Primary Mortgage Market Survey (PMMS) conducted by Freddie Mac; the Mortgage Interest Rate Survey (MIRS) conducted by the Federal Housing Finance Board (FHFB); the Survey of Consumer Finances (SCF) sponsored by the Federal Reserve Board; the Residential Finance Survey (RFS) by the U.S. Census Bureau; the Panel Study of Income Dynamics (PSID), and Consumer Confidence Index by the University of Michigan, among others, have been used in countless studies published in top real estate, economic, and finance journals. See for example, Berkovec (1989), Berkovec and Fullerton (1992), Berkovec et al. (2001), Courchane et al. (2004), Coulibaly and Li (2009), Boehm and Schlottmann (2009), Benjamin et al. (2009), and Guiso et al. (2012).

${ }^{8}$ It is important that the data was collected at a regularly scheduled meeting where attendees were not previously informed about the data collection effort. This process was followed to avoid concerns of selfselection bias.

${ }^{9}$ See Seiler et al. (2012b) for a thorough review and description of this procedural method.
} 


\section{Results}

Panel A of Table 1 reports the results associated with trials where the borrower's request for a loan modification is granted versus rejected. As part of the experimental design, I intentionally made the modification extremely modest to determine if cooperation by the lender, even if not economically meaningful, would send a signal of goodwill to the borrower and encourage them not to default. In the current investigation, I made both the interest rate reduction and principal reduction result in just a $\$ 100$ reduction in monthly mortgage payment. ${ }^{10}$ Indeed, there is a statistically significant difference between the two samples. To investigate whether an interest rate reduction versus principal forgiveness is more likely to reduce stated willingness to strategically default, I segment the sample accordingly and find that principal reductions are significantly more effective at encouraging continued payment. This finding is consistent with the knowledge that negative equity is the primary driver of strategic mortgage defaults. That is, if negative equity is the primary cause of strategic default, then reducing the degree of negative equity would seem to mitigate its occurrence.

In the second column, I report the results from asking homeowners to share their opinion of the morality of their willingness to strategically default in the given situation. As can be seen throughout the tables, there is a high correlation between the borrower's moral stance on the issue and their stated willingness to stop making payments. This result is entirely consistent with Guiso et al. (2012) and Seiler et al. (2012a).

Panel B reports the variants of the experiment where all borrowers within the pool were denied loan modifications. I further disaggregate the results by considering three pairs of scenarios. In the first pair, I differentiate between a local bank where the borrower has done business since he was 18 years old versus the loan being purchased on-line by a bank who has subsequently resold the loan to an owner whose name the borrower does not recognize. This test is designed to examine the impact of changing lending relationships over time and if these changes might impact strategic default behavior. As hypothesized, borrowers whose loans are held by an on-line lender are significantly more likely to walk away from their contractual obligations confirming my supposition that it is easier to breach a contract with someone you do not know or with whom you do not otherwise have a relationship.

The second set of lender characteristics involves the comparison of financially conservative banks versus ones that have engaged in egregious behavior including predatory lending practices, excessive risk-taking, and receiving government bailout funds. Once again, as hypothesized, the egregious banks are associated with a significantly greater borrower willingness to strategically default confirming that borrowers state a willingness to penalize lenders who are deemed untrustworthy. This result remains robust across all four specifications of both willingness and the moral position taken by the borrower.

${ }^{10}$ Both types of modification caused the homeowner's monthly payment to go from $\$ 1,600$ down to $\$ 1,500$. 
Table 1 Homeowner strategic default and morality measures by modification and bank type. This table shows summary results for the 21 variations of the experiment. The sample size, mean reported willingness to strategically default, mean morality of strategic default, and the corresponding dummy variable means are provided for each. Panel A reports the results by modification type. Panel B shows results from when the bank rejected the borrower's modification request, while Panels $\mathrm{C}$ and $\mathrm{D}$ report experimental variants associated with interest rate and principal reductions, respectively. The total sample size is 880

\begin{tabular}{|c|c|c|c|c|c|}
\hline Variable & Obs. & $\begin{array}{l}\text { Mean Strategic } \\
\text { Default } \\
\text { Likelihood }\end{array}$ & $\begin{array}{l}\text { Mean Morality } \\
\text { Score }\end{array}$ & $\begin{array}{l}\text { Mean Strategic } \\
\text { Default } \\
\text { Dummy }\end{array}$ & $\begin{array}{l}\text { Mean } \\
\text { Morality } \\
\text { Dummy }\end{array}$ \\
\hline
\end{tabular}

880

Panel A: Modification Type

\begin{tabular}{|c|c|c|c|c|c|}
\hline No Modification & 289 & $3.55^{* *}$ & $3.53 * *$ & 0.34 & 0.33 \\
\hline Modification & 591 & $3.25^{* *}$ & $3.22 * *$ & 0.29 & 0.28 \\
\hline $\begin{array}{c}\text { Interest Rate } \\
\text { Reduction }\end{array}$ & 311 & $3.39 *$ & 3.32 & 0.30 & 0.29 \\
\hline Principal Reduction & 280 & $3.10 *$ & 3.11 & 0.29 & 0.26 \\
\hline \multicolumn{6}{|c|}{ Panel B: No Modification } \\
\hline Control Group & 46 & 3.20 & 3.33 & 0.24 & 0.26 \\
\hline Local Bank & 42 & $3.43 * *$ & 3.17 & $0.36^{*}$ & $0.26^{*}$ \\
\hline On-line Bank & 40 & $4.57 * *$ & 3.73 & $0.55^{*}$ & $0.45^{*}$ \\
\hline Conservative Bank & 44 & $2.82^{* * *}$ & $3.27 * * *$ & $0.16^{* * *}$ & $0.27 * *$ \\
\hline Egregious Bank & 39 & $4.23 * * *$ & $4.69 * * *$ & $0.49 * * *$ & $0.49 * *$ \\
\hline Defaults are Rare & 41 & 3.12 & 3.15 & 0.24 & 0.24 \\
\hline Defaults are Common & 37 & 3.68 & 3.46 & 0.38 & 0.35 \\
\hline \multicolumn{6}{|c|}{ Panel C: Interest Rate Modification } \\
\hline Control Group & 39 & 3.26 & 3.31 & 0.26 & 0.33 \\
\hline Local Bank & 45 & 3.13 & 3.22 & 0.24 & 0.24 \\
\hline On-line Bank & 46 & 3.52 & 3.41 & 0.37 & 0.33 \\
\hline Conservative Bank & 45 & 3.78 & 3.40 & 0.38 & 0.31 \\
\hline Egregious Bank & 50 & 3.68 & 3.76 & 0.32 & 0.36 \\
\hline Defaults are Rare & 45 & 3.04 & 2.96 & 0.24 & 0.22 \\
\hline Defaults are Common & 41 & 3.27 & 3.07 & 0.27 & 0.24 \\
\hline \multicolumn{6}{|c|}{ Panel D: Principal Reduction Modification } \\
\hline Control Group & 37 & 3.62 & 3.22 & 0.41 & 0.30 \\
\hline Local Bank & 46 & 2.63 & $3.37 *$ & 0.15 & $0.33^{*}$ \\
\hline On-line Bank & 40 & 2.53 & $2.53 *$ & 0.18 & $0.15^{*}$ \\
\hline Conservative Bank & 43 & 3.91 & 3.16 & 0.47 & 0.21 \\
\hline Egregious Bank & 38 & 3.26 & 3.82 & 0.34 & 0.37 \\
\hline Defaults are Rare & 39 & 2.62 & 2.72 & $0.15 *$ & 0.23 \\
\hline Defaults are Common & 37 & 3.16 & 2.97 & $0.32 *$ & 0.24 \\
\hline
\end{tabular}

Asterisk marks indicate statistical significance between paired rows based on Independent-Samples T-tests. *** Significant at $1 \%$; * Significant at $5 \%$; Significant at $10 \%$

Bold indicates statistical significance at a minimum level of $95 \%$ when each row is compared to its corresponding control group 
The final pair of variants relates to the literature on foreclosure contagion. It has been suggested that the greater the number of foreclosures in an area, the more likely other homeowners are to follow suit (Immergluck and Smith 2006; Harding et al. 2009; Lin et al. 2009; Rogers and Winter 2009; and Gangel et al. 2012). To test for the social acceptability of strategic default, I compare trials where the borrower is told that mortgage default is relatively rare in their neighborhood versus an environment where default is relatively common. While I do find that stated willingness to strategically default is higher when mortgage defaults are more common, the result is not statistically significant.

Panel $\mathrm{C}$ is similar to Panel A except in Panel C, an interest rate modification has been granted. Even though the loan modification was truly modest (a reduction in the monthly mortgage payment of only $\$ 100$, or $6.25 \%$ ), there is a significant decline in default proclivity. Far more interesting, however, is that there is now no significant difference between the three pairs of variants (local versus on-line; conservative versus egregious; common versus rare defaults). The implication of this result is that even banks that have engaged in predatory lending practices, excessive risk-taking and received government bailout funds can wipe the strategic default proclivity slate clean simply by granting a very modest loan modification. I attribute this remarkable result to the lender sending a clear signal of cooperation, thus removing the borrower's desire to punish the lender for previous bad behavior. This is an extremely important finding for lenders who are suffering from poor loan portfolio performance and/or a poor public image.

Panel D is similar to the previous panel except in these trials the borrower was granted a principal reduction loan modification. Recall that the amount by which the borrower's monthly payment declined is the same as in Panel C. In all three variant pairs, I once again see a lack of significance in terms of the borrowers' stated willingness to default in each of these scenarios. The conclusion to be drawn is that even a modest interest rate or principal reduction loan modification will go a long way to reduce the strategic default incentive to stop paying one's mortgage.

Because an experiment allows for only one variable to change at a time, univariate statistics are sufficient to measure the impact of that change (Bloomfield and Anderson 2012). As such, the results just presented represent the main contribution of the study. Still, I recognize the appetite to learn as much as possible about the strategic default process. As such, I now turn my attention to a lesser focus of this investigation. Specifically, in a multi-variate context, what are the potential borrower demographic variables that influence a homeowner's stated willingness to strategically default on his mortgage?

Model (I) in Table 2 shows that having previously defaulted on a mortgage is a significant determinant in explaining a borrower's stated willingness to strategically default. In Model (II), the univariate results (from Table 1) are supported by observing the significant dummy variables associated with on-line banks and egregious banks. Finally, Model (III) extends the list of independent variables by including potential demographic variables that might affect borrower strategic default proclivity. The first significant demographic variable is a dummy variable for borrowers under the age of 45. Consistent with Seiler et al. (2012a), I find that younger 
Table 2 Determinants of Homeowner Stated Willingness to Strategically Default. This table presents the results of three regressions investigating the determinants of homeowners' stated willingness to strategically default on their mortgage under various conditions. In Model (I), I consider only whether or not the borrower has previously defaulted on a mortgage. The six variants associated with being rejected for a loan modification request is added in Model (II). Model (III) adds demographic variables to the equation

\begin{tabular}{llll}
\hline Variables & (I) & (II) & (III) \\
\hline Intercept & $5.168^{* * *}(0.731)$ & $4.947^{* * *}(0.725)$ & $5.426^{* * *}(0.808)$ \\
Previous Default Dummy & $0.926^{* *}(0.371)$ & $0.868^{* *}(0.368)$ & $0.943^{* *}(0.391)$ \\
Experimental Variants & & $0.217(0.329)$ & $0.409(0.362)$ \\
Local Bank & & $1.320^{* * *}(0.337)$ & $1.368^{* * *}(0.349)$ \\
On-Line Bank & $-0.393(0.322)$ & $-0.326(0.360)$ \\
Conservative Bank & $0.953^{* * *}(0.341)$ & $0.967 * *(0.345)$ \\
Egregious Bank & $-0.110(0.333)$ & $0.269(0.365)$ \\
Defaults are Rare & $0.464(0.350)$ & $0.595(0.376)$ \\
Defaults are Common & & \\
Demographic Variables & & & $0.351^{* *}(0.172)$ \\
Below Age 45 Dummy & & & $-0.061(0.050)$ \\
Income & & & $-0.276^{*}(0.163)$ \\
Positive Net Worth & & & $-0.310(0.222)$ \\
Caucasian Dummy & & & $0.424^{* * *}(0.153)$ \\
Male Dummy & & $-0.231(0.163)$ \\
Married Dummy & & & $4.379 * * *$ \\
F-Statistic & & .000 & .000 \\
p-value & $6.242^{* * *}$ & & \\
\hline
\end{tabular}

*** Significant at $1 \% ; *$ Significant at $5 \%$; Significant at $10 \%$

borrowers are more willing to walk away from their loans. The second significant demographic variable is if the borrower has a positive net worth. My supposition is that positive net worth borrowers are attractive candidates for banks to pursue when a deficiency judgment is granted on behalf of the lender. Alternatively, borrowers with no assets are reasonably less concerned when walking away from underwater property since they have no assets for the lender to come after. The final significant variable is being a male. Men are much more likely to indicate a willingness to strategically default than women. As explained in Bruekner (2000), the profile described above is associated with borrowers who have lower transaction costs associated with default, or at least a greater ability to recover financially after having incurred such costs.

The previous tables report the results from my sample of 880 homeowners. As a robustness check, and in accordance with Seiler et al. (2012b), I next collected a second sample this time focusing on much more informed, professionals within the field. This second sample consists of 36 members of a local chapter of the national organization, Mortgage Bankers Association (MBA). Data were collected during a live presentation and results were stored using an Instant Response Device (IRD). Because it is not practical to split a live sample into multiple sub-groups and 
Table 3 Mortgage Banker Strategic Default and Morality Meble shows summary results from a live sample collection effort from members of the Mortgage Bankers Association. The mean reported willingness to strategically default, mean morality of strategic default, and the corresponding dummy variable means are provided for four banking scenarios where requests for a loan modification were denied. The total sample size is 36

\begin{tabular}{lllll}
\hline Variable & $\begin{array}{l}\text { Mean Strategic } \\
\text { Default Likelihood }\end{array}$ & $\begin{array}{l}\text { Mean Morality } \\
\text { Score }\end{array}$ & $\begin{array}{l}\text { Mean Strategic } \\
\text { Default Dummy }\end{array}$ & $\begin{array}{l}\text { Mean Morality } \\
\text { Dummy }\end{array}$ \\
\hline Local Bank & $2.71^{* * *}$ & 2.48 & $0.18^{* *}$ & $0.15^{*}$ \\
On-line Bank & $3.53^{* * *}$ & 2.76 & $0.35^{* *}$ & $0.24^{*}$ \\
Conservative Bank & $3.09 * * *$ & $2.66^{* * *}$ & $0.27 * *$ & $0.14^{* * *}$ \\
Egregious Bank & $4.27 * * *$ & $3.54 * * *$ & $0.42^{* *}$ & $0.40^{* * *}$ \\
\hline
\end{tabular}

Asterisk marks indicate statistical significance between paired rows based on Paired-Samples T-tests. *** Significant at $1 \% ; *$ Significant at $5 \%$; Significant at $10 \%$

conduct simultaneous, concurrent experiments, I employed a "within subjects" design and focused on just the four statistically significant variants from Table 1. ${ }^{11}$ This simply means that the same 36 mortgage lenders answered the stated willingness to strategically default questions for all four scenarios. ${ }^{12}$

Table 3 is thus similar to the format reported in Table 1. Consistent with my earlier findings, there is a significant difference between the stated willingness to strategically default when comparing local banks with on-line institutions. Moreover, egregious banks were once again associated with a statistically significantly greater default proclivity than conservative lenders. While the consistency across samples confirms the central hypotheses examined in this study, the results from the MBA sample are somewhat surprising given how detrimental strategic defaults are to the lending industry.

Having established that a borrower's perception of a lender's character affects one's willingness to strategically default on a mortgage, I next turn my attention to the perceptions of homeowners (from both samples). I begin by selecting a sample of 16 banks, eight of which received government bailout funds and eight of which did not. I asked both samples to identify which banks did and did not receive government funds. Regular homeowners were correct only $55.04 \%$ of the time, not significantly different from the score that would have been achieved by flipping a coin to guess the answer. Surprisingly, MBA members were only correct $52.27 \%$ of the time. I would have guessed this number would be higher given the fact that these individuals work within the industry.

Both samples were next provided with the total number of banks within the United States and then asked how many of them received government bailout funds. The homeowner sample estimated that twice as many banks received funds than the number that actually had. The MBA sample estimated a number that was three times

\footnotetext{
${ }^{11}$ Another reason to restrict the sample to just four of the variants is because my access to mortgage bankers is limited in both number of members and time each member is willing to take from their day to participant in my study.

${ }^{12}$ Recall that with the first sample, I employed a "between subjects" design, meaning that each homeowner viewed only one variant of the experiment.
} 
Table 4 Homeowner and mortgage banker policy questions. This table reports the results from a series of additional questions that have potential policy implications. The Homeowner sample represents the 880 homeowners whose responses were collected during my core experiment, whereas the Mortgage Banker sample reveals the results collected from 36 Mortgage Bankers Association (MBA) members collected during a live experiment

\begin{tabular}{lll}
\hline Variable & Homeowner Sample & Mortgage Banker Sample \\
\hline Bank Bailout Score & $55.04 \%$ & $52.27 \%$ \\
Number of Bailed out Banks & 1,541 & 2,240 \\
Did their bank get bailed out? & & \\
Yes & $16.8 \%$ & $40.6 \%$ \\
No & $26.3 \%$ & $6.3 \%$ \\
I do not know & $56.9 \%$ & $53.1 \%$ \\
Perception that Loan Servicer=Loan Owner & $89.2 \%$ & $77.4 \%$ \\
Best Modification & 4.74 & 4.11 \\
Principal Reduction & $37.3 \%$ & $42.9 \%$ \\
Equally Effective & $32.5 \%$ & $37.1 \%$ \\
Interest Rate Reduction & $30.2 \%$ & $20.0 \%$ \\
\hline
\end{tabular}

too high. When asked if the actual borrower's bank received government bailout funds, over half the borrowers in each group readily admitted to not knowing. This appears to be completely consistent with the low scores from the first two metrics previously discussed. Taken together, these first three revelations indicate that borrowers' general perception is that far more banks are egregious than they actually are. This, combined with my earlier findings, does not bode well for an industry that views strategic default as detrimental to its health.

It has often been suggested that homeowners do not differentiate between the servicer of their loan and the underlying owner of their loan. To test for this potential discrepancy, I asked participants in both samples to identify who services their loans (To whom do you make your mortgage payments?). I then asked who owns their loan. In my larger sample, $89.2 \%$ of borrowers believe their servicer and their lender is the same entity. Among MBA members, $77.4 \%$ think the two are the same. While I have no way of knowing the true number for either sample, I do know that Fannie Mae and Freddie Mac own roughly half of all outstanding loans as of the end of $2011 .{ }^{13}$ I further know that these two GSEs do not service their own loans. Thus, even if I assume all other loans are owned and serviced by the same institution (which, of course, they are not), both estimates provided by my two sample participants are far too high.

The final result from Table 4 relates to the type of modification that borrowers believe will most effectively reduce the likelihood of strategic default. Operating on a scale from 1 (principal reduction is more effective) to 9 (interest rate reduction is

\footnotetext{
${ }^{13} \mathrm{http}: / /$ www.freddiemac.com/corporate/company profile/recovery/delinquencies.html accessed on March 29, 2012. Source: FDIC, Freddie Mac, Fannie Mae, Mortgage Bankers Association, HUD, CoreLogic, Federal Reserve. Note: Data as of December 31, 2011. Freddie and Fannie own slightly more than half of the loans in terms of total number of mortgages, and just under half of all loans in terms of dollar amount outstanding (i.e., Fed Flow-of-Funds).
} 
more effective), both samples agree that principal reduction is a better course. That said, roughly one third of each group indicated that both were equivalent. I appreciate the complexity of the debate between which type of loan modification is both more effective and practical, and certainly understand the legal issues surround securitization, moral hazard, and the like. As such, it is beyond the scope of the current study to further investigate this line of research.

In sum, homeowners dramatically overestimate the egregious behavior of banks, have virtually no idea which banks have and have not received government bailouts, yet they will penalize banks for having behaved badly. Moreover, even in cases where the borrower can accurately identify their bank as having behaved egregiously, they stand a good chance of taking out their frustration on the wrong institution (i.e., they do not know to differentiate between the servicer of their loan and the true owner of the loan). Clearly, the industry should take the opportunity to clear up these misconceptions to potentially reduce the incidence of strategic mortgage default.

\section{Conclusions}

This study documents an extreme mis-match between borrowers' perceptions of bank behavior and the bank's actual behavior. Borrowers have virtually no idea which banks have and have not received government bailout funds (not even their own bank). Moreover, they grossly over-estimate the total number of banks that took bailout funds. Finally, borrowers do not know to even differentiate between the servicer of their loan and the owner of their loan. Then, using the theory of Inequity Aversion as the basis of my hypotheses, I propose that an individual's utility function consists of more than just wealth maximization. I find that borrowers also derive utility from knowing they are being treated fairly, and are thus willing to substitute some level of wealth in favor of punishing wrongdoing banks.

Specifically, I find that borrowers are significantly less willing to strategically default on a local bank with whom they have a long-term relationship as opposed to when their loan was made on-line through a nameless-faceless lender who then sold their loan to another institution whose name the borrower does not recognize. Moreover, borrowers are significantly more willing to default on banks who have behaved in an egregious manner such as engaging in predatory lending and excessive risktaking practices and received government bailout funds when compared to banks who adopt conservative financial lending practices. These results remain robust even when a second sample of more informed lending industry professions were tested.

When investigating which homeowners are more likely to state a willingness to strategically default, I find that those who were denied a loan modification, those who have previously defaulted on a mortgage, those under the age of 45 , those with higher positive net worth, and males are more likely to walk away. The results from this study have a multitude of implications for the lending industry. At a minimum, it would seem pertinent to the owner of loans to select as their servicer a bank that is widely known to have not received government bailout funds. A servicer who then advertises that they have behaved conservatively throughout the crisis would then seem to be able to reduce the delinquency rate of the loans they service. 


\section{References}

Benjamin, J., Chinloy, P., \& Winkler, D. (2009). Labor supply, flexible hours and real estate agents. Real Estate Economics, 37(4), 747-767.

Berkovec, J. (1989). A general equilibrium model of housing consumption and investment. Journal of Real Estate Finance and Economics, 2(3), 157-172.

Berkovec, J., \& Fullerton, D. (1992). A general equilibrium model of housing, taxes, and portfolio choice. Journal of Political Economy, 100(2), 390-429.

Berkovec, J., Kogut, D., \& Nothaft, F. (2001). Determinants of the ARM Share of FHA and conventional lending. Journal of Real Estate Finance and Economics, 22(1), 23-41.

Bloomfield, R., \& A. Anderson (2012). Experimental Finance. Working paper, Cornell University.

Boehm, T., \& Schlottmann, A. (2009). The dynamics of homeownership: eliminating the gap between African American and white households. Real Estate Economics, 37(4), 599-634.

Bruekner, J. (2000). Mortgage default with asymmetric information. Journal of Real Estate Finance and Economics, 20(3), 251-274.

Coulibaly, B., \& Li, G. (2009). Choice of mortgage contracts: evidence from the survey of consumer finances. Real Estate Economics, 37(4), 659-673.

Courchane, M., Surette, B., \& Zorn, P. (2004). Subprime borrowers: mortgage transitions and outcomes. Journal of Real Estate Finance and Economics, 29(4), 365-392.

Fehr, E., \& Schmidt, K. (1999). A theory of fairness, competition, and cooperation, Quarterly Journal of Economics, 114(3), 817-868.

FICO (2011). Predicting Strategic Default. April, white paper.

Gangel, M., Seiler, M., \& Collins, A. (2012) Exploring the foreclosure contagion effect using Agent-Based Modeling. Journal of Real Estate Finance and Economics, forthcoming.

Guiso, L., Sapienza, P., \& Zingales, L. (2012). The determinants of attitudes towards strategic default on mortgages. Journal of Finance, forthcoming.

Güth, W., Schmittberger, R., \& Schwarze, B. (1982). An experimental analysis of ultimatum bargaining. Journal of Economic Behavior and Organization, 3(4), 367-388.

Harding, J., Rosenblatt, E., \& Yao, V. (2009). The contagion effect of foreclosed properties. Journal of Urban Economics, 66(3), 164-178.

Immergluck, D., \& Smith, G. (2006). The external costs of foreclosures: the impact of single-family mortgage foreclosures on property values. Housing Policy Debate, 17(1), 57-79.

Kahneman, D., Knetsch, J., \& Thaler, R. (1986). Fairness and the assumptions of economics. In R. Hogarth \& M. Reder (Eds.), Rational choice. Chicago: University of Chicago Press.

LaCour-Little, M. (2008). Mortgage termination risk: a review of the recent literature. Journal of Real Estate Literature, 16(3), 297-326.

Lin, Z., Rosenblatt, E., \& Yao, V. (2009). Spillover effects of foreclosures on neighborhood property values. Journal of Real Estate Finance and Economics, 38(4), 387-407.

Rabin, M. (1993). Incorporating fairness into game theory and economics. American Economic Review, 83 (5), 1281-1302.

Rogers, W., \& Winter, W. (2009). The impact of foreclosures on neighboring housing sales. Journal of Real Estate Research, 31(4), 455-479.

Sanfey, A., Rillig, J., Aronson, J., Nystrom, L., \& Cohen, J. (2003). The neural basis of economic decisionmaking in the ultimatum game. Science, 300, 1755-1758.

Seiler, M., Seiler, V., Lane, M., \& Harrison, D. (2012a). Fear, shame, and guilt: economic and behavioral motivations for strategic default. Real Estate Economics, forthcoming.

Seiler, M., Lane, M., \& Harrison, D. (2012b). Mimetic herding behavior and the decision to strategically default. Journal of Real Estate Finance and Economics, forthcoming.

White, B. (2010). Underwater and not walking away: shame, fear, and the social management of the housing crisis. Wake Forest Law Review, 45, 971-1023.

Wyman, O. (2010). Understanding strategic default in mortgages. Experian Report. 